\title{
Quality assessment of commercially supplied drinking jar water in Chittagong City, Bangladesh
}

\author{
Sohana Akter Mina ${ }^{1} \cdot$ Lolo Wal Marzan $^{1} \cdot$ Tasrin Sultana $^{1} \cdot$ Yasmin Akter $^{1}$
}

Received: 27 September 2017 / Accepted: 16 January 2018 / Published online: 27 January 2018

(C) The Author(s) 2018. This article is an open access publication

\begin{abstract}
Chittagong is the second most populated city in Bangladesh where drinking water is supplied using small jar. Water quality is an important concern for the consumers and, therefore, the present study was done by collecting 38 drinking jar water samples from Chittagong City, Bangladesh to determine the microbial contamination and physiochemical properties. Molecular study was done by the PCR amplification of $16 \operatorname{SrDNA}, \mathrm{LacZ}$ and uidA gene for the identification of bacteria, coliform and fecal coliform. TVC, MPN and different biochemical test were done for enumeration and identification. TDS, $\mathrm{pH}$, and metals (Fe, $\mathrm{As}, \mathrm{Pb}$ and $\mathrm{Cr}$ ) concentration were also measured. No heavy metal (As, $\mathrm{Pb}$ and $\mathrm{Cr}$ ) was found in any of the water samples but Fe was detected in low concentrations $(0.02-0.05 \mathrm{mg} / \mathrm{l})$. TDS and $\mathrm{pH}$ level were normal in all samples. But microbial contaminations were $(60.53$ and $50 \%)$ recorded in molecular and biochemical test, respectively. The range of total bacterial count was $\left(1.5 \times 10^{2}-1.6 \times 10^{4}\right) \mathrm{cfu} / \mathrm{ml}$. The total coliform count $\left(\mathrm{TCC}^{\mathrm{m}}\right)$ was recorded $(14-40)$ in $100 \mathrm{ml}$ of water samples. The presence of total coliform and fecal coliform was 26.32 and $18.42 \%$, respectively, in PCR analysis but in biochemical test those were 18.42 and $15.78 \%$, respectively. A total of 11 bacterial species: Enterobacter aerogenes, Escherrichia coli, Aeromonas, Bacillus sp., Cardiobacterium, Corynebacterium, Clostridium, Klebsiella sp., Lactobacillus, Micrococcus sp., Pseudomonas sp. were found. This study indicates that some of the drinking jar water samples were of poor quality which may increase the risk of water-borne disease. Hence, the producer of drinking jar water has to implement necessary quality control steps.
\end{abstract}

Keywords Drinking water $\cdot$ Coliforms $\cdot$ Bacteria

\section{Introduction}

Supply of safe drinking water can improve people health, improve their productivity and livelihoods. Sustainable development and poverty reduction can be achieved by the availability and accessibility of clean fresh water (Tekpor et al. 2017).In Bangladesh filtered commercially supplied drinking jar water is distributed on restaurants, cafeteria, medical, school, diagnostic center, residential areas and almost in all industries and offices as pure water. It is consumed by the majority of the population in Chittagong City, Bangladesh. This crowded city has been suffering from various water-related problems along with insufficient drinking water supply (Zuthi et al. 2009).

Sohana Akter Mina

sohanageb@cu.ac.bd

1 Department of Genetic Engineering and Biotechnology, University of Chittagong, Chittagong 4331, Bangladesh
The quality of drinking water may be ascertained by its microbiological and some important physiochemical test such as $\mathrm{pH}$, TDS and metal concentration. Detection of bacterial contamination and physicochemical properties have attracted great attention worldwide due to public health impacts. Naturally found some opportunistic pathogens may cause disease in immune suppressed people, mostly among infants and young children. Pseudomonas aeruginosa, Klebsiella sp., Aeromonas sp. and certain slow growing bacteria are the common example of opportunistic organisms (WHO 1993). Ten major water-borne diseases are accountable for over 28 billion disease episodes annually in developing countries, where diarrheal diseases are the big killers especially in infants and diarrheal disease is highly endemic also (Clasen et al. 2007).

The prevalence of fecal indicator and heterotrophic bacteria with levels exceeding drinking water guideline has been reported (Olaoye and Onilude 2009; Kassenga et al. 2007; Svagzdiene et al. 2010). Pathogenic microorganisms in bottled water can multiply during storage and can reach a level 
which can be detrimental to consumers. Microorganisms such as Aeromonas sp., Pseudomonas sp., Shigella sp. and Salmonella sp. have been demonstrated to survive and multiply in bottled water (Ahmed et al. 2013). Consequently to ensure that bottled water is safe for drinking, quality standards have to be strictly enforced. According to WHO (2004), the number of fecal coliforms should be zero in drinking water.

Biochemical as well as cultural methods for the detection of bacteria and coliform have some drawbacks such as long incubation period, contamination with other microorganisms, lack of precision and required sensitivity and poor identification of VBNC (Viable but not culturable bacteria) bacteria. But molecular techniques are accurate, rapid and sensitive method for the study of specific pathogenic bacteria (Clifford et al. 2012).

Water-borne diseases can often be attributed to exposure to increase level of heavy metal concentrations of both organic and inorganic contaminants which exist naturally, but their concentration has increased as a result of anthropogenic activities (Huang et al. 2014). Generally, human is exposed to different heavy metals by ingestion of drinking water. These heavy metals like arsenic, barium, cadmium, chromium, lead, mercury, selenium, silver, etc. can cause different life threatening disorders like cancer, asthma, etc. in human (Lars 2003).

The primary aim of this study was to assess the microbiological contamination, concentration of metal like-Fe, As, $\mathrm{Pb}$ and $\mathrm{Cr}$ and physicochemical properties $-\mathrm{pH}$ and TDS of commercially supplied drinking jar water in Chittagong City, Bangladesh. Therefore, this research will play a great significance in addressing the public health concerns that are being generated by the supplied drinking jar water phenomenon in developing countries, especially Bangladesh. Moreover, this research will shed light on the necessary steps to ensure safe and quality drinking water supply in city areas.

\section{Materials and methods}

\section{Study area}

Twenty-six areas in the Chittagong City of Bangladesh were selected for this study Fig. 1. The areas that cover the Chittagong city where drinking jar water is sold by hawkers.

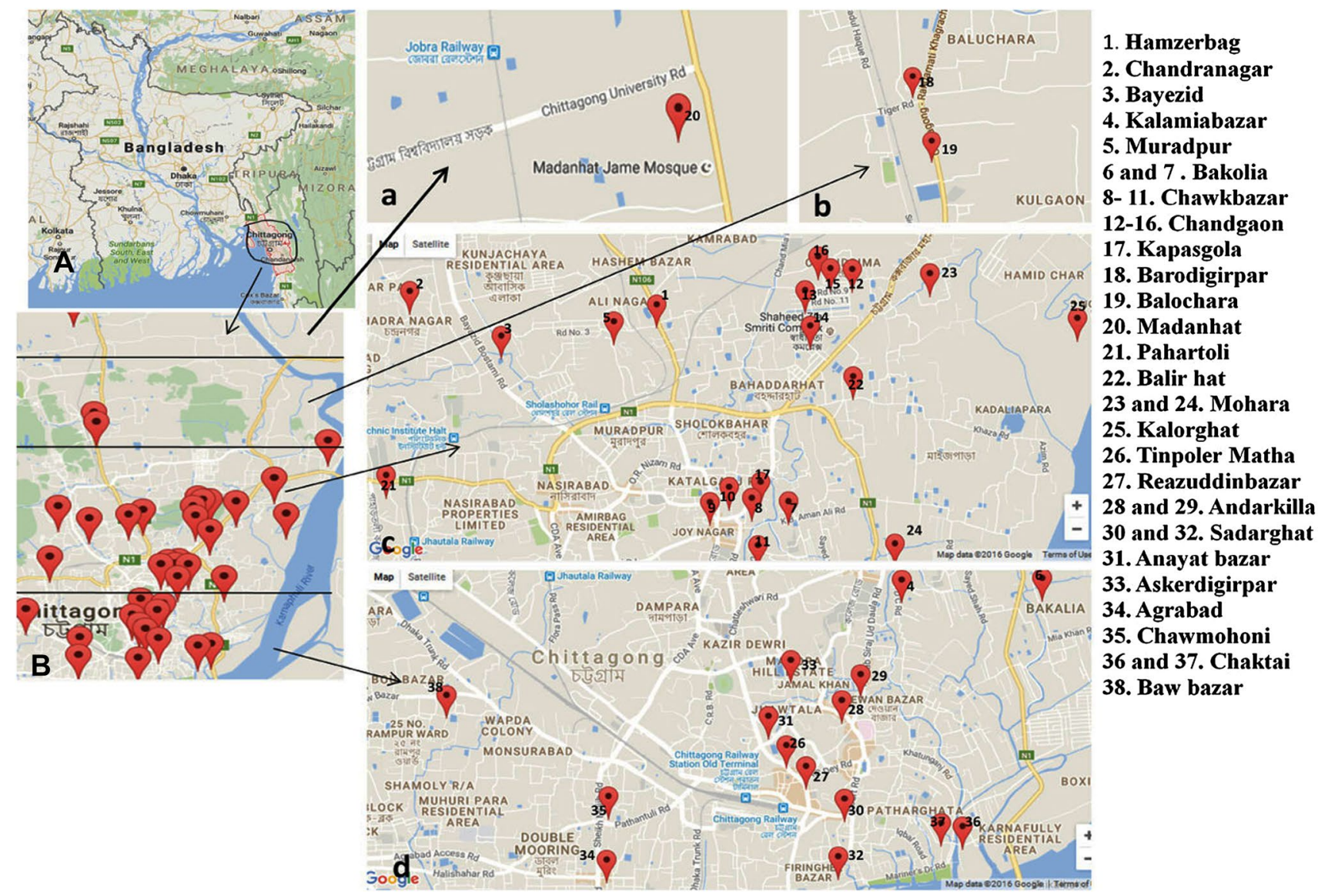

Fig. 1 a Sites from where sample were collected in Chittagong City. b: $a-d$ Location of areas from where commercially supplied drinking jar water samples were taken 


\section{Water sample collection}

A total of 38 commercially supplied drinking jar water samples were collected from residential locations of 26 different areas of Chittagong Metropolitan Area (Fig. 1). The samples were collected in two sets of sterile capped containers where one set is for physiochemical tests and another for microbiological analysis. The collected samples were taken to the laboratory on ice clean containers (Marzan et al. 2017). Samples for microbiological analysis were stored at $4{ }^{\circ} \mathrm{C}$ before commencement of analysis and samples for physiochemical tests were analyzed immediately. Hygienic and aseptic practices were executed during sampling of drinking jar water.

\section{Physiochemical analysis}

At first $\mathrm{pH}$ was measured by $\mathrm{pH}$ meter. SS, TDS and TS were also measured manually. Concentrations of Iron, Arsenic, Lead and Chromium ( $\mathrm{Fe}, \mathrm{As}, \mathrm{Pb}$ and $\mathrm{Cr}$ ) were analyzed in all brands of drinking jar water samples using standard atomic absorption spectrophotometric methods (Shimadzu AA-7000, Japan).

\section{Microbiological analysis}

\section{Enumeration}

Microbial population was enumerated using total viable count (TVC) method. TVC was conducted on nutrient agar media by means of serial dilution agar plating method (Marzan et al. 2017). For agar plating, dilution $10^{-1}$ and $10^{-2}$ water samples was used. One milliliter of appropriate dilution suspension was transferred into Petri plates containing nutrient agar medium and then those plates were incubated at $37^{\circ} \mathrm{C}$ for $24 \mathrm{~h}$. Then, viable colonies were counted and the results were expressed in $\mathrm{cfu} / \mathrm{ml}$. Plating of water samples was performed for three times (Olaoye and Onilude 2009).

\section{Bacterial isolation}

The isolation was conducted following the methods described by Uddin et al. (2011) where spread and pourplate techniques were adopted. Isolation of pure cultures was performed by the streak plate method on nutrient agar media ( $\mathrm{pH}=7.0$ ) and EMB (Eosin-Methylene blue agar). To confirm purity and cell shape, Gram staining was carried out on the respective isolates. The bacterial isolates were sub-cultured on agar slants of their respective media at regular intervals to maintain viability as well as metabolic activities. After that, agar slants were stored at $4{ }^{\circ} \mathrm{C}$. These isolates were maintained in replicates where one is used as a working culture for the identification test. On the other hand, pure colonies were preserved in liquid media containing $20 \%$ (vlv) glycerol and stored at $-80^{\circ} \mathrm{C}$ until further analysis.

\section{Characterization of isolates}

The primary identification of the isolates was conducted on the basis of their cultural characteristics on agar plates and microscopic observations. Then, the secondary characterization of the isolates was performed on the basis of their biochemical characteristics, which helped in distinguishing the isolates sharing similar morphological characteristics (Williams et al. 1989; Aneja et al. 2004).

\section{Biochemical detection of fecal coliform and total coliform}

A most probable number (MPN) test was done to count the total coliform in drinking water samples by Mackie and McCartney (1996) method which was conducted sequentially in three phases. First presumptive test was then confirmed and the completed test was performed. Double lactose broth and single lactose broth tubes were incubated with different volumes of drinking jar water samples, such as-10, 1.0 and $0.1 \mathrm{ml}$ in presumptive test. Tubes that were positive for gas production after $24 \mathrm{~h}$ incubation at $37{ }^{\circ} \mathrm{C}$ were incubated in brilliant green lactose bile broth for confirmed test and positive tubes were used to calculate the MPN of coliform in drinking jar water samples following the statistical table described by Mackie and McCartney (Colle et al. 1996). Completed test was done by the inoculation in petriplates containing tergitol-7 agar medium. Finally, Gram staining was used to establish that coliforms were present in samples.

\section{Molecular identification of bacteria, fecal coliform and total coliform}

\section{DNA extraction}

Genomic DNA was extracted from drinking jar water according to Aghababaee et al. (2012) and stored at $-20^{\circ} \mathrm{C}$. DNA concentration was measured by Thermo scientific NanoDrop 2000 spectrophotometer (Thermo Scientific, USA).

\section{PCR analysis for the identification of bacteria, coliform and fecal coliform}

In this study, PCR detection of bacteria, coliform and fecal coliform was carried out using the previously published primers and targeted gene (Fatemeh et al. 2014; Aghababaee et al. 2012). Primer specificity was determined by searching for similar sequences in microbial genome using

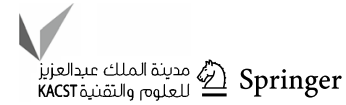


the Basic Local Alignment Search Tool (BLAST). In each experiment, positive control was carried out as the standard genomic DNA along with sample run without DNA template as negative control element. PCR mixture, primers targeted gene name, cycling parameters amplicon size are shown in Table 1. A PCR thermal cycler (Nyx Technik) was used for amplification and the PCR products were analyzed by $1.5 \%$ agarose gel electrophoresis.

\section{Results}

\section{Physiochemical analysis}

Commercially supplied drinking water of 38 brands was analyzed for quality assessment. The $\mathrm{pH}$ value of analyzed water samples varied from 6.50 to 7.50 . The lowest $\mathrm{pH}$ value was found at Pahartoli sample ID-M21 and the highest $\mathrm{pH}$ value was found at Chandannagar ID-M2. TDS of all samples varied from 0 to $0.00015 \mathrm{gm} / 1$. As, $\mathrm{Pb}$ and $\mathrm{Cr}$ were not found in any of the water samples, but iron was detected in low concentration which was $(0.02-0.05 \mathrm{mg} / \mathrm{l})$.

\section{Microbial analysis}

As summarized in Table 3, among 38 branded drinking water microorganisms were detected in 19 samples, which is $50 \%$ by biochemical test. On the other hand, PCR analysis of $16 \mathrm{~s} r \mathrm{rNA}$ gene of 38 isolates resulted in $23(60.53 \%)$ samples positive (Table 3, Fig. 2). The standard plate count indicates that the total bacterial load in the drinking water was in the ranges of 150-16,000 cfu/ml, in different areas. In this study, 11 bacterial species such as Enterobacter aerogenes, Escherichia coli, Aeromonas, Bacillus sp., Cardiobacterium, Corynebacterium, Clostridium, Klebsiella sp., Lactobacillus sp., Micrococcus sp., and Pseudomonas aeruginosa were found (Table 2). Two bacterial species, e.g., $E$. coli and Micrococcus sp. showed the maximum occurrence which was 15.78 and $13.16 \%$ of total positive samples in biochemical test (Table 3 ).

Table 1 Target genes, primers, cyclic condition, PCR mixture and amplicon size

\begin{tabular}{|c|c|c|c|c|}
\hline Target & Primer sequence $5^{\prime}-3^{\prime}$ & Cycling parameters & Composition of PCR mixture & $\begin{array}{l}\text { Ampli- } \\
\text { con size } \\
\text { (bp) }\end{array}$ \\
\hline $\begin{array}{l}\text { Common bacterial: } \\
\text { 16SrDNA }\end{array}$ & $\begin{array}{l}\text { AGAGTTTGATCCTGG } \\
\text { CTCAG }^{\mathrm{a}} \\
\text { GACTACCAGGGTATC } \\
\text { TAAT }^{\mathrm{b}}\end{array}$ & $\begin{array}{l}5 \mathrm{~min} \text { at } 95^{\circ} \mathrm{C}, 35 \text { cycles of } 95^{\circ} \mathrm{C} \text { for } \\
40 \mathrm{~s}, 57^{\circ} \mathrm{C} \text { for } 50 \mathrm{~s} \text { and } 72^{\circ} \mathrm{C} \text { for } 1 \mathrm{~min}\end{array}$ & $\begin{array}{l}\text { For } 20 \mu \mathrm{l}: 10 \mu \mathrm{l} \text { master mix, } 4 \mu \mathrm{l} \\
\text { template, } 2 \mu \mathrm{l}^{\mathrm{a}} \text { and } 2 \mu \mathrm{l}^{\mathrm{b}}, 3 \mu \mathrm{l} \text { water }\end{array}$ & 800 \\
\hline Coliform: Lac Z & $\begin{array}{l}\text { ATGAAAGCTGGC } \\
\text { TACAGGAAGGCC } \\
\text { CACCATGCCGTGGGT } \\
\text { TTCAATATT }^{\mathrm{a}}\end{array}$ & $\begin{array}{l}5 \mathrm{~min} \text { at } 95^{\circ} \mathrm{C}, 25 \text { cycles of } 95^{\circ} \mathrm{C} \text { for } \\
1 \mathrm{~min}, 60^{\circ} \mathrm{C} \text { for } 1 \mathrm{~min} \text { and } 72^{\circ} \mathrm{C} \text { for } \\
1 \mathrm{~min}\end{array}$ & $\begin{array}{l}\text { For } 20 \mu \mathrm{l}: 10 \mu \mathrm{l} \text { master mix, } 4 \mu \mathrm{l} \\
\text { template, } 2 \mu \mathrm{l}^{\mathrm{a}} \text { and } 2 \mu \mathrm{l}^{\mathrm{b}}, 3 \mu \mathrm{l} \text { water }\end{array}$ & 874 \\
\hline $\begin{array}{l}\text { Fecal coliform: }(E \text {. coli }) \\
\quad \text { uidA }\end{array}$ & $\begin{array}{l}\text { TGGTAATTACCGACG } \\
\text { AAAACGG }^{\mathrm{a}} \\
\text { ACGCGTGGTTACAGT } \\
\text { CTTGCG }^{\mathrm{b}}\end{array}$ & $\begin{array}{l}5 \mathrm{~min} \text { at } 95^{\circ} \mathrm{C}, 30 \text { cycles of } 95^{\circ} \mathrm{C} \text { for } \\
50 \mathrm{~s}, 62^{\circ} \mathrm{C} \text { for } 50 \mathrm{~s} \text { and } 72{ }^{\circ} \mathrm{C} \text { for } 1 \mathrm{~min}\end{array}$ & $\begin{array}{l}\text { For } 20 \mu \mathrm{l}: 10 \mu \mathrm{l} \text { master mix, } 4 \mu \mathrm{l} \\
\text { template, } 2 \mu \mathrm{l}^{\mathrm{a}} \text { and } 2 \mu \mathrm{l}^{\mathrm{b}}, 3 \mu \mathrm{l} \text { water }\end{array}$ & 147 \\
\hline
\end{tabular}

${ }^{\mathrm{a}}$ Forward primer

${ }^{\mathrm{b}}$ Reverse primer

Fig. 2 a Thermo scientific $1 \mathrm{~kb}$ DNA ladder; b PCR amplification of LacZ (Lane 1, Lane 2, Lane 3 and Lane 4 indicate E. coli, Enterobacter, Klebsiella sp. and Pseudomonas sp., respectively), uidA (Lane 5 indicates fecal coliform $E$. coli) and 16SrDNA (Lane 6 indicates bacteria) gene. Lane $\mathrm{M}$ indicates Thermo scientific 1 kb DNA ladder
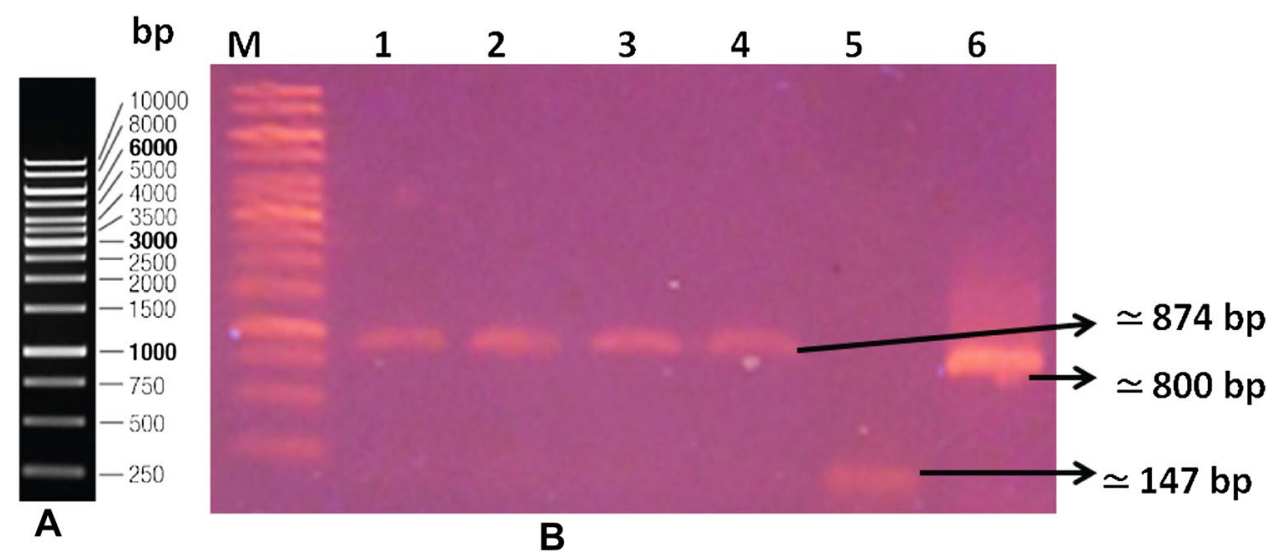


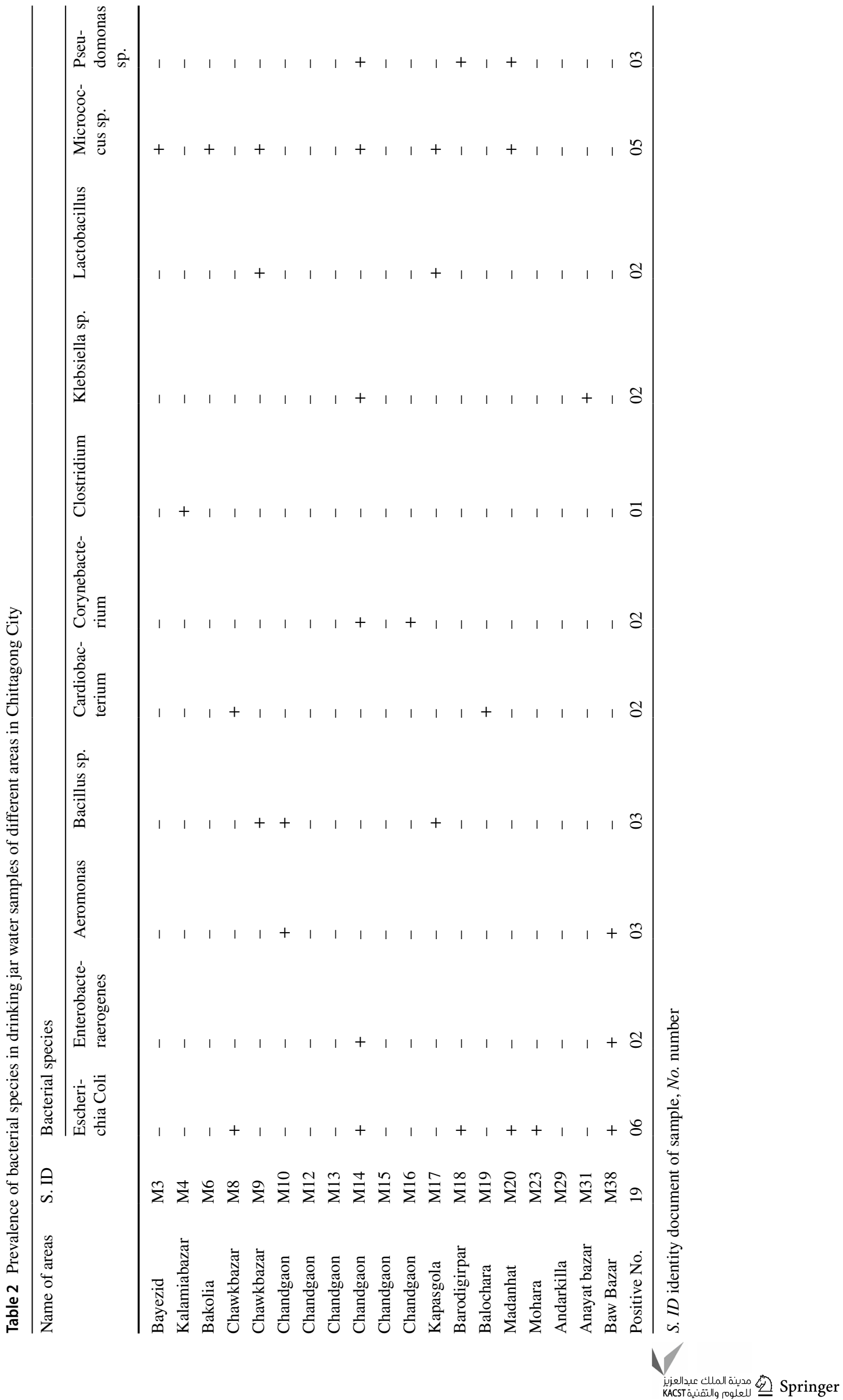


Table 3 PCR and biochemical test result of commercially supplied drinking jar water taken from different regions of Chittagong City, Bangladesh

\begin{tabular}{lllll}
\hline $\begin{array}{l}\text { Number of } \\
\text { total sample }\end{array}$ & $\begin{array}{l}\text { Name of } \\
\text { methods }\end{array}$ & $\begin{array}{l}\text { Occurrence } \\
\text { of bacteria } \\
(\%)\end{array}$ & $\begin{array}{l}\text { Occurrence } \\
\text { of coliform } \\
(\%)\end{array}$ & $\begin{array}{l}\text { Occurrence } \\
\text { of fecal } \\
\text { coliform }\end{array}$ \\
\hline 38 & $\begin{array}{l}\text { PCR test } \\
\text { Biochemical } \\
\text { test }\end{array}$ & 60.53 & 26.32 & 18.42 \\
& & 18.42 & 15.78 \\
\hline
\end{tabular}

For the identification of coliform, MPN test was done where $7(18.42 \%)$ samples showed positive. The standard plate count indicates that the total coliform in the drinking water was in the ranges of 14-40 in $100 \mathrm{ml}$ of water samples in different areas and fecal coliform was detected in 6 (15.78\%) of total samples. But PCR analysis of LacZ gene for coliform and uidA gene for total coliform resulted in 10 (26.32\%) positive for faecal coliform and $7(18.42 \%)$ positive for only fecal coliform (Table 3, Fig. 2).

\section{Discussion}

Contamination of drinking water is one of the greatest health problems worldwide, particularly in developing countries. During this study, PCR analysis was done for the detection of prevalence of bacteria, coliform and fecal coliform using $16 S r D N A, L a c Z$ and uidA gene, respectively. The biochemi$\mathrm{cal}$ and cultural tests were also done for the enumeration of total viable count (TVC) of bacteria and total coliform count $\left(\mathrm{TCC}^{\mathrm{m}}\right)$, and to identify the different isolates up to genus to species level present in commercially supplied drinking jar water samples.

In this study, the prevalence of bacteria in commercially supplied drinking jar water is 60.53 and $50 \%$ of total sample by PCR analysis and cultural test, respectively, in Chittagong City, Bangladesh. Imperfect personal hygiene of handlers and environmental hygiene have been reported to contribute significantly to the contamination in commercially supplied drinking water in developing countries (Dada et al. 2009; Ashbolt et al. 2004). All these previous studies highlighted that the prevalence of indicator organisms in the water constitutes a serious threat to the community, and they asked for good manufacturing practices by the processors and handlers.

The occurrence of Enterobacter aerogenes, E. coli, Klebsiella sp. and Pseudomonas sp. during this study in drinking water is of primary importance because these constitute a major part of coliform organism. This result implies that the water samples were potentially contaminated from fecal sources and as such were not safe for consumption. Coliform is used as water quality indicator. According to
WHO (2011), the number of faecal coliforms should not be observed in $100 \mathrm{ml}$ of drinking water. In this study, 18.42\% drinking water samples for different areas showed that the presence of fecal coliforms (FCC), i.e., E. coli (Table 3), indicates the contamination of drinking water. Enteropathogenic $E$. coli causes diarrhea, food-borne disease and vomiting (Suthar et al. 2009). Moreover, E. coli is also responsible for urinary tract infection. Other coliforms such as Enterobacter aerogenes, Klebsiella sp. and Pseudomonas aeruginosa are detected during this study where Enterobacter aerogenes creates food spoilage and Klebsiella pneumonia causes urinary tract infection and pneumonia. P. aeruginosa has been previously reported in the bottled water (Ahmed Ahmed et al. 2013; Svagzdiene et al. 2010). The organism may be harmful to newborns and elderly patients because it can multiply and reach to harmful number very quickly. Moreover, being a primary cause of disease Pseudomonas aeruginosa is often identified as an indicator of other bacterial contaminations of fecal origin (Warburton et al. 1994). Occurrence of coliforms shows the danger of fecal contamination and the consequent hazard of contracting disease through pathogenic organisms.

Along with other microbial isolates related to public health concern, Aeromonas $s p$. was also detected which is known to create septicemia gastrosenterities in young children, elderly and immunocompromised people. On the other hand, Bacillus cereus, Corynebacterium and Clostridium are mainly responsible for diarrhea. Moreover, Micrococcus luteum is the second highest prevalent microorganism during this study which is a common flora (Madigan and Martinko 2005). During this study, the bacteria found in the drinking water samples in Chittagong could be due to the sources of water used by the processors because pathogens and indicator organisms in water sources mainly depend on the intrinsic physical and chemical characteristics of the drainage system, human activities and animal sources that release pathogens to the environment (WHO 1984).

Drinking water containing high levels of metals, such as cobalt, copper, iron, manganese, molybdenum, selenium, and zinc or toxic metals such as aluminium, arsenic, barium, cadmium, chromium, lead, mercury, selenium, and silver, may be hazardous to health. In this study, concentrations of $\mathrm{Fe}, \mathrm{As}, \mathrm{Pb}$ and $\mathrm{Cr}$ were measured where no $\mathrm{As}, \mathrm{Pb}$ and $\mathrm{Cr}$ were detected in water samples. Usually high iron concentrations may not constitute a direct health risk but this could have a bad impact on odor and taste (Smedley et al. 1995). During this study, concentrations of iron were within the limits of BDS standard. Moreover, identified $\mathrm{pH}$ and TDS levels were also within the limits of WHO guideline and BDS standard.

Bangladesh Standards and Testing institute (BSTI) provides guidelines and approval for the production of commercially supplied drinking water for handling, processing as 
well as distribution from factory to consumer. But, many of the processors fail to do so. Consequently, supplied drinking jar water is contaminated with disease-causing pathogens and bacteria. Moreover, many of the defaulting processors may not have been licensed for their operations which could be the reason for more contamination of supplied drinking water.

\section{Conclusion}

The overall study indicates that commercially supplied drinking jar water of different areas of Chittagong City contains a wide variety of enteropathogenic bacteria. So people of this region are under severe threat of water-related diseases and health risk. Therefore, the processors of commercially supplied drinking jar water of Chittagong City have to improve their processing operations, especially in terms of hygiene and to ensure strict compliance with guidelines as set by BDS standard.

Acknowledgement This research was done in the 'Molecular Biology Laboratory' of the department of Genetic Engineering and Biotechnology, University of Chittagong, Bangladesh. This research work is supported by Planning and Development Offices, University of Chittagong, Chittagong-4331, Bangladesh. Grant Ref 133/P\&D/738(18)/2016.

Authors contribution SAM designed the project. SAM and TS carried out the laboratory experiments and SAM prepared the manuscript draft. LWM, SAM and YAR prepared and reviewed the final manuscript. All authors read and approved the final manuscript.

\section{Compliance with ethical standards}

Conflict of interest The authors declare that they have no conflict of interests.

Open Access This article is distributed under the terms of the Creative Commons Attribution 4.0 International License (http://creativeco mmons.org/licenses/by/4.0/), which permits unrestricted use, distribution, and reproduction in any medium, provided you give appropriate credit to the original author(s) and the source, provide a link to the Creative Commons license, and indicate if changes were made.

\section{References}

Aghababaee H, Jebelli MA, Izanloo H, Tekyeh S (2012) Comparison of PCR technique with MPN method in identification of coliform bacteria in water. Arch Des Sci 65(4):29-33

Ahmed W, Yusuf R, Hasan I, Goonetilleke A, Toze S, Gardener T (2013) Fecal indicators and bacterial pathogens in bottled water from Dhaka, Bangladesh. Braz J Microbiol 44(1):97-103

Ashbolt NJ (2004) Microbial contamination of drinking water and disease outcome in developing regions. Toxicology 198(1-3):229-238
Clasen T, Schmidt WP, Rabie T, Roberts I, Cairncross S (2007) Interventions to improve water quality for preventing diarrhoea: systematic review and meta-analysis. BMJ 334(7597):782

Clifford RJ, Milillo M, Prestwood J, Quintero R, Zurawski DV, Kwak YI (2012) Detection of bacterial 16S rRNA and identification of four clinically important bacteria by real-time PCR. PLoS ONE 7(11):e48558

Colle G, Fraser AG, Marmion BP, Simmons A (1996) Mackie and McCartney practical medical microbiology, 14th edn. Churchill livingstone, New York

Dada AC (2009) Sachet water phenomenon in Nigeria: assessment of the potential health impacts. Afr J Microbiol Res 3(1):15-21

Fatemeh D, Reza ZM, Mohammad A, Salomeah K, Reza AG, Hossein S (2014) Rapid detection of coliforms in drinking water of Arak city using multiplex PCR method in comparison with the standard method of culture (most probably number). Asian Pac J Trop Biomed 4(5):404-409

Huang Z, Pan XD, Wu PG, Han JL, Chen Q (2014) Heavy metals in vegetables and the health risk to population in Zhejiang, China. Food Control 36:248-252

Kassenga GR (2007) The health-related microbiological quality of bottled drinking water sold in Dar es Salaam, Tanzania. J Water Health 5(1):179-185

Lars J (2003) Hazards of heavy metal contamination. Br Med Bull 68:167-182

Madigan M, Martinko J (2005) Brock biology of microorganisms, 11th edn. Prentice Hall, New Jersey

Marzan LW, Hossain M, Mina SA, Akter Y, Chowdhury AMMA (2017) Isolation and biochemical characterization of heavy-metal resistant bacteria from tannery effluent in Chittagong City, Bangladesh: bioremediation viewpoint. Egypt J Aquat Res 43:65-74

Olaove OA, Onilude AA (2009) Assessment if microbiological quality of sachet-packaged drinking water in Wester Nigeria and its public health significance. Public Health 123:729-734

Smedley PL, Edmunds WM, West JM, Gardner SJ, Pelig-Ba KB (1995) Health problems related to groundwater in the Obuasi and Bolgatanga Areas, Ghana. British Geological Survey Technical Report WC/95/43, Natural Environment Research Council Polaris House, North Star Avenue Swindon, p 122

Suthar S, Chhimpa V, Singh S (2009) Bacterial contamination in drinking water: a case study in rural areas of northern Rajasthan, India. Environ Monit Assess 159:43-50

Svagzdiene R, Lau R, Page RA (2010) Microbiological quality of bottled water brands sold in retail outlets in New Zealand. Water Sci Technol 10(5):689-699

Tekpor M, Akrong M, Asmah MH, Banu RA, Ansa EDO (2017) Bacteriological quality of drinking water in the Atebubu-Amantin district of the Brong-Ahafo region of Ghana. Appl Water Sci 7:2571-2576

Uddin MA, Haque HM, Noor R (2011) Isolation and identification of pathogenic Escherichia coli, Klebsiella spp. and Staphylococcus spp. in raw milk samples collected from different areas of Dhaka City, Bangladesh. Stamford J Microbiol 1(1):19-23

Warburton DW, Bowen B, Konkle A (1994) The survival and recovery of Pseudomonas aeroginosa and its effect on Salmonella in water: methodiology to test bottled water in Canada. Can J Microbiol 40(12):987-992

WHO (2004) Guidelines for drinking water quality, 3rd edn. World Health Organization, Geneva

Williams ST (1989) Bergey's manual of systematic bacteriology. Williams and Wilkins, Baltimore

World Health Organization (1984) Guidelines for drinking water quality recommendations. WHO, Geneva

World Health Organization (1993) Guidelines for drinking water quality. Recommendations, vol 3. WHO, Geneva

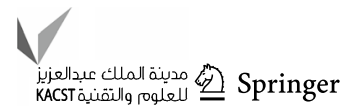


World Health Organization (2011) Guidelines for drinking water quality. 4th Edn. World Health Organization, Geneva. http://apps. who.int/iris/bitstream/10665/44584/1/9789241548151_eng.pdf. Accessed 22 Jan 2018

Aneja KR (2004) Experiments in microbiology, plant pathology and biotechnology, 4th edn. New Age International (P) Ltd. Pub, New Delhi
Zuthi MFR, Biswas M, Bahar MN (2009) Assessment of supply water quality in the Chittagong City of Bangladesh. ARPN J App Sci 4:73-80

Publisher's note Springer Nature remains neutral with regard to jurisdictional claims in published maps and institutional affiliations. 